\title{
Retraction Note to: Slug down-regulation by RNA interference inhibits invasion growth in human esophageal squamous cell carcinoma
}

Peng Tang ${ }^{1+}$, Zhentao $\mathrm{Yu}^{1+}{ }^{1+}$ Kejun Zhang ${ }^{2}$, Yu Wang ${ }^{2}$, Zhongliang $\mathrm{Ma}^{3}$, Shaoyan Zhang ${ }^{3}$, Dong Chen ${ }^{2^{*}}$ and Yanbing Zhou ${ }^{2}$

\section{Retraction Note to:BMC Gastroenterol (2011) 11:60} https://doi.org/10.1186/1471-230X-11-60

The Editor has retracted this article after concerns were raised regarding the figures and the contents of the article, including:

- Inaccurate description of results in the main text and figure legends;

- Inconsistencies between the descriptions of results and figures;

- Overlap between images in Figs. 4a, b (western blot) and 6a, b (cell images);

- Issues with western blot images presented in Figs. 3 and 4.

The Editor no longer has confidence in the results and conclusions presented.

None of the authors have responded to correspondence from the editor or publisher about this retraction.

\begin{abstract}
Author details
${ }^{1}$ Department of Esophegeal Oncology, Key Laboratory of Cancer Prevention and Therapy, Cancer Institute and Hospital of Tianjin Medical University, Tianjin, 300060, People's Republic of China. ${ }^{2}$ Department of Surgery, The Affiliated Hospital of Medical College, QingDao University, QingDao 266003, Shan Dong Province, People's Republic of China. ${ }^{3}$ Department of Laboratory, the Affiliated Hospital of Medical College, QingDao University, QingDao 266003, Shan Dong Province, People's Republic of China.
\end{abstract}

Published online: 22 October 2021

\section{Publisher's Note}

Springer Nature remains neutral with regard to jurisdictional claims in published maps and institutional affiliations. original author(s) and the source, provide a link to the Creative Commons licence, and indicate if changes were made. The images or other third party material in this article are included in the article's Creative Commons licence, unless indicated otherwise in a credit line to the material. If material is not included in the article's Creative Commons licence and your intended use is not permitted by statutory regulation or exceeds the permitted use, you will need to obtain permission directly from the copyright holder. To view a copy of this licence, visit http://creativecommons.org/licenses/by/4.0/. The Creative Commons Public Domain Dedication waiver (http://creativecommons.org/publicdomain/zero/1.0/) applies to the data made available in this article, unless otherwise stated in a credit line to the data. 